\title{
The impact of advisory services on Iranian SME performance: An empirical investigation of the role of professional accountants
}

\author{
Y. Kamyabi* \\ Department of Accounting, Ayatollah Amoli Science and Research Branch, \\ Islamic Azad University, Amol, Iran \\ ykamyabi344s@yahoo.com \\ S. Devi \\ Faculty of Business and Accounting, University of Malaya, \\ 506033 Lembah Pantai, Kuala Lumpur, Malaysia
}

Received December 2010

\begin{abstract}
The role of small and medium enterprises (SMEs) is recognized globally given their contribution to total productivity and job opportunities. However, the majority of SMEs tend to fail due to a lack of marketing knowledge and managerial skills or technical expertise. Professional accountants are in a unique situation to help SME owner/managers to achieve their business objectives and bridge the skills gap. Therefore, this paper aims to identify the factors that affect the decisions of owner/managers of SMEs in Iranian manufacturing sector to utilise the professional accountants' advisory services and to examine the impact of these advisory services on SME performance using the Resource-Based View (RBV) of the firm. Based on a questionnaire survey data of 658 Iranian manufacturing SMEs, our regression analysis reveals a significant positive relationship between utilisation of professional accountants' advisory services and three independent variables, namely, knowledge of owner/manager, competitive intensity and complexity of marketing decisions. Furthermore, we evidence that the use of advisory services is significant and positively associated with SME performance. More importantly, utilisation of professional accountants' advisory services partially mediates the relationship between knowledge of owner/manager, competitive intensity and complexity of marketing decisions and firm performance. Therefore, we provide a specific, theoretically and empirically grounded prediction of how utilisation of professional accountants' advisory services influences performance with implications for theory and practice.
\end{abstract}

*To whom all correspondence should be addressed.

\section{Introduction}

Given the pivotal role of small and medium enterprises (SMEs) in the global economy in contributing to total productivity and job opportunities (Gunasekaran, Marri \& Grieve, 1999; OECD, 2009; Ulubasoglu, Akdis \& Kök, 2010), and in particular, in emerging economies ${ }^{1}$ (Blackburn \& Jarvis, 2010), we focus on the performance of Iranian SMEs. Iranian SMEs are an important source of employment generation and diversification of economy as in many other developed and developing countries around the world (Bayati \& Taghavi, 2007; ILO, 2003). A majority of private sector enterprises in Iran are SMEs (Bayati \& Taghavi, 2007; ILO, 2003). However, most SMEs fail due to a lack of marketing knowledge and managerial skills or capabilities and technical expertise (Dyer \& Ross, 2008). Indeed, "SMEs are more vulnerable now for many reasons: not only has the traditional challenge of accessing finance continued to apply, but new, particularly supply-side, difficulties are currently apparent" (OECD, 2009: 6). Furthermore, the new competitive environment is more

\footnotetext{
${ }^{1}$ The term "emerging economies" and "developing countries" have been used interchangeably throughout this paper.
}

complex (Espino-Rodríguez \& Padrón-Robaina, 2004; Garcia-Teruel \& Martinez-Solano, 2010), and SMEs cannot control the markets in which they operate (Bennett, 2008). Therefore, in this globalised era, as competitive pressures intensify, smaller firms are forced to reduce their costs and seize new opportunities through optimized utilisation of external resources (Mahmoodzadeh, Jalalinia \& Yazdi, 2009). There is a need to scrutinize ways of empowering SMEs (Samujh \& Devi, 2008). Hence, SMEs need advice and support services because of both their economic contributions and their vulnerability to market imperfections (Lowe \& Talbot, 2000). In this context, a transformation in professional accountants' services to their small business clients is critical (Blackburn \& Jarvis, 2010). For instance, professional accountants can assist SMEs operating in a competitive environment, to integrate operational considerations within long-term plans (Ismail \& King, 2005) to enhance their sustainability.

Resource-Based View (RBV) posits that given the limited resource or knowledge of smaller firms, it is essential for them to obtain resources from external sources (Hadjimanolis, 2000). By relying on external sources, SMEs harness the capabilities and knowledge they require from 
external service providers (Gilley, Greer \& Rasheed, 2004). Consequently, to conduct the important activities for which the SMEs lack the necessary resources or knowledge internally, services can be obtained from external service providers (McIvor, 2009). Hence, the RBV further encourages the sourcing of SME resources, thereby, linking external sources (outsourcing) with performance (McIvor, 2009). In effect, the RBV lends support to the argument that SME owners/managers use professional accountants as a source of professional services principally as a result of a gap in their internal resource base (Doving \& Gooderham, 2008; Gooderham, Tobiassen, Doving \& Nordhaug, 2004; Blackburn \& Jarvis, 2010). A major concern of the RBV is how a firm's resources or knowledge develop and affect its performance (McIvor, 2009). The RBV suggests that SME performance can be improved through receiving information and advice (Bennett \& Robson, 2004). However, in UK, several studies that examined the association between the utilisation of the professional accountants' advisory services and SME performance (Bennett \& Robson, 1999; Berry, Sweeting \& Goto, 2006; Robson \& Bennett, 2000), have produced inconclusive results. We take cognizance that, these studies have been carried out in the developed and mature economies. We argue therefore, that emerging economies provide unique settings to broaden the theoretical and empirical understanding of SME behaviour (Ulubaşoğlu et al., 2010). Further, Devi and Samujh (2010) evidence a shift towards provision of more non-compliance services to SMEs among professional accountants in Malaysia, an emerging economy ${ }^{2}$. However, the effect of professional accountants' services on SME performance has not been examined in emerging economies. Furthermore, it is debatable whether evidence from developed economies is applicable to economies such as $\operatorname{Iran}^{3}$ (Mashayekhi \& Mashayekh, 2008) due to differing institutional contexts (Devi \& Samujh, 2010) and levels of state intervention in economic activities (Ismail \& Zin, 2009; Ulubaşoğlu et al., 2010). Given that the nature of accountants' services is people-intensive (Everaert, Sarens \& Rommel, 2010), and that there is a resource gap and an increasingly competitive environment faced by SMEs (Blackburn \& Jarvis, 2010), it is timely to explore whether the provision of professional accountants' advisory services is associated with SME performance in an emerging economy. Hence, this paper aims to identify the factors that affect the decisions of owner/managers of the SMEs in the Iranian manufacturing sector to utilise professional accountants' advisory services and to examine the effect of these advisory services on SME performance using the Resource-Based View (RBV) of the firm.

The rest of the discussion is organised as follows: Section two provides the background of the study. Section three develops the research hypotheses utilising the RBV as a theoretical framework to investigate the use of advisory services. Section four explains the research methodology.

\footnotetext{
${ }^{2}$ The World Bank classifies economies as low-income, middle-income, and high-income. Low-income and middle-income economies are referred to as developing countries or emerging economies (http://www.sustainability.com/developing-value/definitionemerging.asp).
}

${ }^{3}$ Iran is part of the low income group and classified as a developing country (http://www.csirwebistad.org/pdf/classi.pdf ).
Section five presents the findings. Section six discusses the implications and concludes with suggestions for future research.

\section{Background of study}

\section{An overview of the Iranian economy}

Iran has a population of 73 million (Nejad, 2010). It has a relatively large segment of young population (Nejad, 2010). Iranian economy is largely dependent on oil revenue (ILO, 2003) as Iran is the second largest oil producer of OPEC after Saudi Arabia (UNIDO, 2003). The dependence on oil exports placed the Iran's economy in a weak position (ILO, 2003; UNIDO, 2003). For example, (Zohari, 2008:18) notes:

"With about 19 per cent of the population living below the poverty line, the GDP of $\$ 599.2$ billion, the real growth rate of 4.3 per cent, unemployment rate of about 22 per cent and inflation rate above 18.5 per cent, the country has a very challenging and unstable economical situation".

Hence, one of the most challenging problems in Iranian economy is to facilitate and produce new jobs for those who are ready to enter the labor market for unemployment position in Iran (Nejad, 2010). For that reason, "Iran is seeking to shift to a market based economy, and in time this will yield benefits by expanding employment opportunities" (ILO, 2003:3). Hence, recognizing the importance of SMEs in generating employment, Iran's national development plans (Third Economic Plan (1999-2004) and The Fourth National Development Plan (2005-2009)) continue to place a great deal of importance on their growth (ILO, 2003). Therefore, to promote employment creation competitiveness, job creation and export promotion, Iranian government needs to support SMEs (Feizpour \& Jamali, 2009).

\section{Professional accountants in Iran}

As a result of the privatisation programmes in 1991 and the requirement for financial reporting with regard to privatisation of economic entities, the Iranian Association of Certified Public Accountants (IACPA) ${ }^{4}$ was established in 2001 as an independent professional body (Mashayekhi \& Mashayekh, 2008; Salehi \& Azary, 2008). The law mandates the use of a member of the Iranian Association of Certified Public Accountants (IACPA), to audit all listed public companies, public joint stock companies, all natural persons and legal entities whose turn-over exceeds eight billion Rials (800000USD) annually or whose total assets exceed sixteen billion Rials (ArabSalehi \& Velashani, 2009). In Iran, the term "professional accountant" refers to members of IACPA and the partners of accounting firms with valid practising certificates who can hold themselves out as CPAs, and set up firms providing accounting, audit, tax and other services (Naderian, 2010). The largest local accounting firms in Iran have less than 200 employees, so there is a big gap between these firms and the international accounting firms in terms of size (Naderian, 2010). Further, there are no Big 4 accounting firms operating in Iran, and all

\footnotetext{
${ }^{4}$ It has currently members who are qualified CPAs.
} 
Iranian accounting firms are small (Naderian, 2010). Iranian small accounting firms offer services such as auditing services (e.g. tax audit and financial audit), accounting services (i.e. accounting systems planning and product / services costing, preparation of financial statements ), advisory services (e.g. tax advice) to most of firms in Iran, particularly, SMEs (Naderian, 2010). Iran has over one million firms (including SMEs and large firms), but only ten thousand $(10,000)$ of such firms are audited (Naderian, 2010). Our point is that those SMEs that are not audited still require accountants' services and where advisory services are used it will enhance their performance. We argue that professional accountants can play a vital role in Iranian SME environment which encompasses almost ninety per cent of the enterprises in Iran (Mirshekary \& Saudagaran, 2005).

\section{The role of professional accountants in SMEs}

Professional accountants play a critical role in assisting SME owner/managers to manage their companies effectively (Mole, 2002). Professional accountants are shown to be of important support to the SME owner/managers in running the firm specifically when it comes to the introduction and implementation of changes (Gooderham et al., 2004). For example, in more complex conditions, professional accountants are in a unique position to guide and assist SME owner/managers to achieve their business objectives (Devi \& Samujh, 2010; Martin, 2005). In the developed countries' context, professional accountants are the main advisers to most businesses on all aspects of doing business (Leung, Raar \& Tangey, 2008). Undeniably, professional accountants maintain a broad base of expertise, enabling them to contribute to the success of companies by providing services beyond the traditional services such as accounting, auditing and assurance services (Greenwood, Suddaby \& Hinings, 2002). This trend is also observed in emerging economies as noted by Devi and Samujh (2010) in the context of Malaysia.

In the UK, many empirical studies show that smaller enterprises used their professional accountant as a source of advisory and support services (Berry et al., 2006; Kirby, Najak \& Greene, 1998; Scott \& Irwin, 2009). In Norway, Gooderham et al. (2004) revealed that professional accountants are a reliable provider of advisory services and support in small companies. In Australia, professional accountants provide financial management and support services for the SME sector (Carey, Simnett, \& Tanewski, 2005; Leung et al., 2008). In New Zealand, Lewis, Massey, Ashby, Coetzer and Harris (2005) found professional accountants were the main source of advice in terms of frequency, usefulness and significance of advice in the SME context. In summary, whilst the professional accountants' role has been examined in the more developed economies, literature on such role in emerging economies such as Iran is scarce except for the limited research conducted in Malaysia (Devi \& Samujh, 2010).

\section{Theoretical framework}

Resource Based-View (RBV), introduced by Penrose (1959), suggests that a company should be considered as a collection of physical and human resources bound together in an organizational structure. Resources and capabilities are considered valuable if they permit a company to exploit opportunities and counter threats in the complex and competitive environment (Marshall, McIvor \& Lamming, 2007; McIvor, 2009). Overall, the RBV concentrates on two key points (Gottschalk \& Solli-Sæther, 2005). First, the RBV indicates a resource should provide economic value and must be currently scarce, difficult to imitate or copy, non-substitutable, and not readily accessible in factor markets to create competitive advantage (McIvor, 2009). Second, resources determine firm performance (Gottschalk \& Solli-Sæther, 2005; McIvor, 2009). Hafeez, Malak and Zhang (2007) classify resources as physical assets and intellectual assets. Physical assets (i.e. plant and equipment) are easily distinguishable due to their visible or tangible existence (Hafeez et al., 2007) compared to intellectual assets including tacit knowledge, employee knowledge, skills or expertise and individual competencies which are intangible (Hafeez et al., 2007). Resources, in the context of accounting, generally refer to knowledge, skill and competence (Everaert, Sarens \& Rommel, 2006; Jayabalan, Raman, Dorasamy \& Ching, 2009). For instance, explicit knowledge in accounting functions is knowledge of generally-accepted accounting rules (Everaert et al., 2006). However, applying those rules in a business environment requires tacit knowledge (Everaert et al., 2006). For professional accountants, tacit knowledge is mainly acquired through practice, which makes it almost impossible to transfer (Hafeez et al., 2007). Additionally, SMEs lack qualified people or knowledge to accomplish the accounting functions required to facilitate decision making by the SME owner/mangers (Everaert et al., 2006). Therefore, professional accountants' services are important to SME owner/managers (Marriott, Marriott, Collis \& Son, 2008). Interestingly, consistent with the RBV theorisation, SMEs use professional accountants as a source of support services and advice to fill the gaps in their internal resource (Doving \& Gooderham, 2008; Everaert et al., 2006; Gooderham et al., 2004; Marriott et al., 2008).Therefore, the RBV of the firm provides a theoretical grounding for the assessment of firm-specific factors that are potentially affect the SME performance (Irwin, Hoffman \& Lamont, 1998). The RBV addresses the central issue of how superior performance can be achieved with regard to other firms in the same market and posits that better performance results from obtaining and using unique resources of the firm (Bennett \& Robson, 2004; Marshall et al., 2007; McIvor, 2009; Gainey \& Klaas, 2003; Roy \& Aubert, 2002).

\section{Owner/managers' knowledge}

The RBV argues that if firms are to grow, they need to obtain expert knowledge from external service providers and then embed the knowledge into their firms (Worrall, 2007). Moreover, the RBV explains that SMEs are unable to carry out the accounting function in-house due to inadequate knowledge and lack of qualified in-house accountants (Everaert et al., 2006; Jayabalan et al., 2009). For example, when SMEs lack the necessary skills and resources to perform accounting functions internally, access to the expertise and specialized knowledge of a professional accountant is clearly the most important reason to outsource 
(Everaert et al., 2006). However, it is shown that SME owner/managers are frequently not aware of the range of support services and advice available to them (Ismail \& King, 2007; Ismail \& Zin, 2009), as well as the benefits of such services (Watson, 2003), or lack support in seeking relevant information (Curran \& Blackburn, 2000). On the other hand, sophisticated SME owner/managers may be aware of the benefits of compensating their own inadequate knowledge or skills by utilising an external service provider (Ismail \& King, 2007; Watson, 2003). For example, Audet and St-Jean (2007) revealed that the SME owner/managers, who knew more about the external service providers, used those services more than SME owner/managers who did not have any information about these services. However, less sophisticated and incapable SME owner/managers might be unaware of their own weaknesses to ask for support and advice, believing they can do it all themselves (Watson, 2003). Effectively, according to RBV, advice augments the firm's resources and helps build capabilities within the firm (Mole, Hart, Roper \& Saal, 2009: 560). Hence, it is hypothesized that:

H1: The utilisation of professional accountants' advisory services is positively associated with SME owner/managers' knowledge.

\section{Competitive intensity}

SMEs are unable to continue when they face intense competitive pressure because their resource gap does not permit them to adapt their product (Gooderham et al., 2004; Blackburn \& Jarvis, 2010). For example, the RBV explains that the firm that faces intense competition (with higher competitive intensity) needs more resources and support than the firm that does not face competitive pressure (less competitive intensity) (Gooderham et al., 2004; Worrall, 2007). More importantly, as competitive intensity increases, SME owner / managers should learn how to exploit external resources to assist their firms to become more productive and remain competitive (Worrall, 2007). Accordingly, one possible way to mitigate competitive pressure is to obtain sufficient resources by employing qualified persons to serve in-house (Gooderham et al., 2004). However, given the insufficient number of qualified professional accountants, recruiting in-house accountants may be difficult and costly. Therefore, we expect SMEs will turn to external professional accountants for advisory and support services (Berry et al., 2006; Devi \& Samujh, 2010). For example, Gooderham et al. (2004) indicate that when a smaller firm is in a vulnerable position, they refer to a professional accountant as a source of support and advice to attain competitive advantage. As a result, our hypothesis is as follows:

H2: The utilisation of professional accountants' advisory services is positively associated with competitive intensity.

\section{Complexity of marketing decisions}

The RBV explains that smaller enterprises need to acquire external support and advice to broaden their market for achieving competitive advantage (Marriott et al., 2008). In fact, whether the owner/manager of the firm needs to obtain external support and advice is dependent on the nature of the market within which the firm is operating (Johnson, Webber $\&$ Thomas, 2007). For example, "the market conditions and regulatory environment within which SMEs are operating is constantly changing and as a corollary, the demand for business advisory services will also be evolving" (Blackburn \& Jarvis, 2010: 7). Moreover, whilst the owner/managers of the firm may be an expert or proficient in the product markets within which they operate, they may not be proficient in accounting and financial management issues, or may lack other important skills and expertise (Collis \& Jarvis, 2002; Devi \& Samujh, 2010; Marriott \& Marriott, 2000; Pineda, Lerner, Miller \& Phillips, 1998). Although market issues are not regulated, as accounting issues, Pineda et al. (1998) reported that SME owner/managers also see market issues as accounting issues. Therefore, they may engage professional accountants when they make marketing decisions (Blackburn \& Jarvis, 2010).However, evidence suggests that SME owner/managers seek specialised advisory and support services from a professional accountant where needed (Sian \& Roberts, 2009). Dyer and Ross (2008) found that complexity of marketing decisions is significantly associated with business advice. Thus, we hypothesise a positive association between the use of advisory services and complexity of marketing decisions as follows:

H3: The utilisation of professional accountants' advisory services is positively associated with complexity of the marketing decisions.

\section{SME performance}

The RBV argues that resources are the determinants of firm performance (Gottschalk \& Solli-Sæther, 2005; McIvor, 2009). Bennett and Robson (1999) examined the association between SMEs' utilisation of the professional accountants' business advice and employment growth which they classified in three stages: (1) declining/stable, (2) medium growth, and (3) fast growth. They concluded that the professional accountants' business advice is associated with employment growth. Furthermore, Robson and Bennet (2000) investigated the relationship between professional accountants' business advice and SME performance which they categorized into three aspects: (1) change in number of staff, (2) percentage change in firm turnover and (3) change in profitability per employee. However, they did not find any association between business advice and SME performance. Berry et al. (2006) examined the effect of four types of accountants' advisory services (e.g. business advice, emergency advice, financial management support and statutory advice) on SME growth. They report that "the degree of use of a range of external advice was positively related to the growth rate of SMEs" (p.33). Similarly, Dyer and Ross (2008) investigated the use of business advice by the small business owner and its impact on firm performance. They measured performance based on perceptions regarding financial measures such as amount of profits, profit as percentage of sales, profit as percentage of investment, growth in sales and growth in profits. They concluded business advice is significantly positively associated with firm performance. Consequently, based on 
RBV and earlier discussions, we hypothesise that the firm performance is associated with the direct use of professional accountants' advisory services as follows:

H4: The utilisation of professional accountants' advisory services is positively associated with firm performance.

\section{Utilisation of professional accountants' advisory services: A mediating role}

Dyer and Ross (2008) found that utilisation of advisory services plays a mediating role on the relationship between the complexity of marketing decisions and firm performance. Although there is no empirical research that attempts to examine the utilisation of professional accountants' advisory services as the mediator, but in line with Dyer and Ross (2008)'s finding, we argue that the interplay between owner/managers' knowledge, competitive intensity and complexity of marketing decisions, and the utlisation of accountants' advisory services will enhance firm performance. In the other words, the owner/manager knowledge, competitive intensity and complexity of marketing decisions are expected to influence the intensity of use of the professional accountants' services, which, in turn, influences the firm's performance. Consequently, based on the discussion above, our hypotheses are as follows:

H5: Utilisation of professional accountants' advisory services mediates the relationship between owner/ managers' knowledge and firm performance.

H6: Utilisation of professional accountants' advisory services mediates the relationship between competitive intensity and firm performance.

H7: Utilisation of professional accountants' advisory services mediates the relationship between complexity of marketing decisions and firm performance.

Based on earlier discussion, the research model is shown in Figure 1.

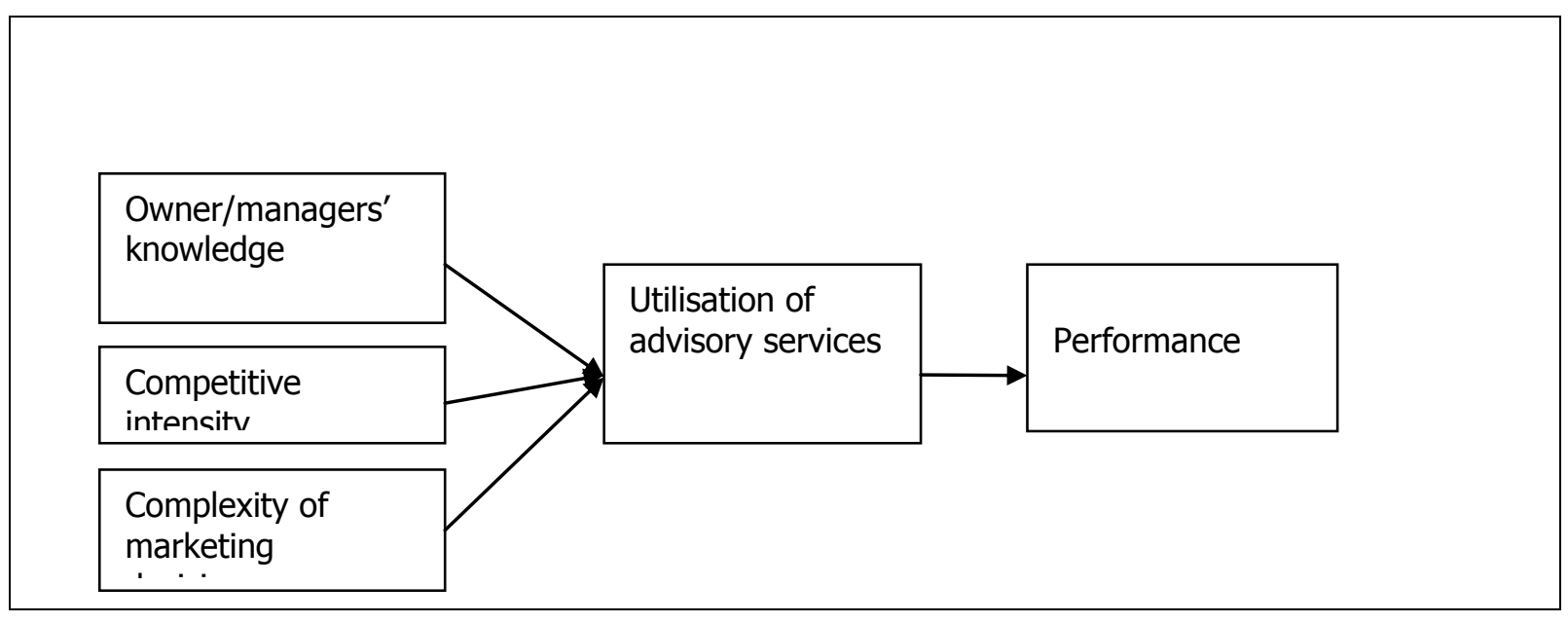

Figure 1: Research model

\section{Research methodology}

\section{Data collection}

In line with prior studies in Iran (Ale Ebrahim, Ahmed \& Taha, 2009; Fathian \& Amiri, 2006; UNIDO, 2003; Zohari, 2008), we defined SMEs as firms employing fewer than 250 employees and exclude micro firms because small and medium sized enterprises (10 - 250 employees) account for a relatively large share of Iran's exports (UNIDO, 2003). We utilised the Iran Small Industries \& Industrial Parks Organization (ISIPO) database (http://www.iraniec.ir), excluding services and public companies, and included only the manufacturing sector. This resulted in a population of 17,100 enterprises. We then randomly selected a sample of 1750 manufacturing SMEs using a systematic probability method. A questionnaire was designed and developed based on prior studies (Doran, 2006; Dyer \& Ross, 2008; Ismail \& King, 2007; Rivard, Raymond \& Verreaul, 2006; Sarapaivanich \& Kotey, 2006) and the questionnaires were sent to each SME owner/manager by post mail on 5 March 2010. The data collection was carried out in two stages. In the first stage, from 1750 questionnaires distributed, only twenty per cent (350 questionnaires) were received. Due to the low response rate, the second stage of data collection was conducted. Questionnaires accompanied by reminder letters were sent again to those SME owner/managers who had not responded to the earlier questionnaire survey. Another 420 responses were received, giving a total of 770 respondents. Nevertheless, 112 questionnaires were excluded because of duplication or incomplete responses by the respondents. Finally, we had only 658 usable useable responses, representing an effective response rate of 38 per cent. The response rate is high in contrast to preceding research of SME context by Everaert, Sarens and Rommel (2007) who obtained a response rate of 10 per cent.

As suggested in Armstrong and Overton (1997), we compared early and late respondents (non-response bias test), but we did not find any significant difference between early and late respondents in terms size (measured by the number of employees). Further, there is no significant difference between early and late respondents for the dependent variable or independent variables. 


\section{Variable measurement}

The variables were measured and rated on a seven point Likert-type scale and found adequately high Cronbach's alpha for all variables (above 70\%). The details of the variable measurement are presented in Table 1.

\section{Dependent variable}

Firm Performance as dependent variable was previously tested and validated by Sarapaivanich and Kotey (2006). Thus, we first asked respondents to indicate the level of the importance attached to the four financial (profitability, growth in sales, return on assets and cash flow) and three non-financial (lifestyle, independence and job security) performance goals on a 7-point Likert type ranging from 1not at all important to 7-very important. Then, respondents were asked to indicate their satisfaction with the seven financial and non-financial performance goals over the previous two financial years on a 7-point Likert type ranging from 1-strongly dissatisfied to 7-very satisfied

\section{Mediating variable}

After a comprehensive review of the practitioners' literature encompassing the role of the professional accountants and following the suggestion by Dyer and Ross (2008), we believe that the use of accountants' advisory services can have a direct effect, as well as a mediating effect on the relationship between the three independent variables and dependent variable. Accordingly, we selected five types of services provided by professional accountants to the Iranian SME sector which were, incidentally, similar to those derived from Doran (2006). Consequently, we utilised the measurement developed by Gooderham et al.(2004), asking participants to indicate to what extent they utilise a professional accountant as an advisor relating to each item using a 7-point Likert type, where 1 - not at all to 7 - very large degree.

\section{Independent variables}

Owner/managers' knowledge contained nine items that was developed by Ismail and King (2007). We asked respondents to indicate the level of their knowledge of the accounting techniques and IT applications on a 7-point Likert scale from $1=$ no knowledge to $7=$ extensive knowledge.

Competitive Intensity included five items derived from Rivard et al. (2006) and Lamminmaki (2008). We utilised the measurement applied by Rivard et al. (2006), asking respondents to record the intensity of their firm competition for each item on a 7-point Likert scale from $1=$ very weak competition to $7=$ very fierce competition.

Complexity of Marketing Decisions has four items and measured in a similar manner as in Dyer and Ross (2008). Accordingly, we asked participants to identify the factors that affect the success of their business on a 7-point Likert scale, from $1=$ not at all significant, $7=$ extremely significant.

\section{Results}

Our sample included 79 per cent male and 21 per cent female. Most of the respondents were quite well educated, and the average years of managerial experience were high with nearly three-fourth of respondents having over five years of experience. Table 2 shows the descriptive statistics showing the means, standard deviations (S.D) and correlations among the independent variables. The correlation between independent variables was such that multicollinearity is not a concern (Burns \& Bush, 2000).

Table 1: Variable measurement

\begin{tabular}{|c|c|c|c|}
\hline Variables & Items & Source & Cronbach's alpha \\
\hline Performance & $\begin{array}{l}\text { 1-Profitability } \\
\text { 2-Growth in sales } \\
\text { 3-Return on assets } \\
\text { 4-Cash flow } \\
\text { 5-Lifestyle } \\
\text { 6-Independence } \\
\text { 7-Job security }\end{array}$ & Sarapaivanich \& Kotey (2006) & 0,96 \\
\hline Advisory services & $\begin{array}{l}\text { 1-Tax consultancy } \\
\text { 2-Business advice } \\
\text { 3-Management consultancy (e,g, strategy formulation) } \\
\text { 4-Financing advice e,g, banking or lending } \\
\text { 5-Information technology (IT) consultancy }\end{array}$ & $\begin{array}{l}\text { Doran (2006) and Gooderham et } \\
\text { al. (2004) }\end{array}$ & 0,88 \\
\hline Owner/managers' knowledge & $\begin{array}{l}\text { 1-Financial accounting techniques } \\
\text { 2-Management accounting techniques } \\
\text { 3-Word-processing package } \\
\text { 4-Spreadsheet package } \\
\text { 5-Database package } \\
\text { 6-Accounting-based applications } \\
\text { 7-Computer-assisted production management } \\
\text { 8-E-mail } \\
\text { 9-Internet searching }\end{array}$ & Ismail \& King (2007) & 0,90 \\
\hline Competitive intensity & $\begin{array}{l}\text { 1-Product characteristics } \\
\text { 2- Promotional strategies among rivals } \\
\text { 3-Access to distribution channels } \\
\text { 4- Service strategies to customers } \\
\text { 5-Product (Service) variety }\end{array}$ & $\begin{array}{l}\text { Lamminmaki (2008) and Rivard et } \\
\text { al. (2006) }\end{array}$ & 0,84 \\
\hline Complexity of marketing decisions & $\begin{array}{l}\text { 1-Having a large number of customers } \\
\text { 2-Selling to numerous market segments } \\
\text { 3-Having broad geographical markets } \\
\text { 4-Innovative marketing techniques and developing } \\
\text { innovative }\end{array}$ & Dyer \& Ross (2008) & 0,78 \\
\hline
\end{tabular}


Table 2: Descriptive statistics and correlations

\begin{tabular}{|c|c|c|c|c|c|c|c|}
\hline Variables & Mean & S,D & 1 & 2 & 3 & 4 & 5 \\
\hline 1 Performance & 5,25 & 1,10 & 1 & & & & \\
\hline 2 Advisory services & 3,80 & 1,78 & $0,388 * *$ & 1 & & & \\
\hline 3 Owner/managers' knowledge & 4,62 & 1,48 & $0,392 * *$ & $0,443 * *$ & 1 & & \\
\hline 4 Competitive intensity & 4,73 & 1,41 & $0,391 * *$ & $0,429 * *$ & $0,368 * *$ & 1 & \\
\hline 5 Complexity of marketing decisions & 4,73 & 1,61 & $0,305 * *$ & $0,475 * *$ & $0,297 * *$ & 0,360 *** & 1 \\
\hline
\end{tabular}

\section{Hypotheses testing}

\section{Testing for direct effects}

Table 3 shows the regression coefficients and standard error (S,E) for independent variables, The multiple linear regression analysis in Model 1of Table 3 shows a significant positive coefficient for owner/managers' knowledge, suggesting that the utilisation of advisory services is significantly positively associated with the owner/managers' knowledge, thereby confirming Hypothesis $1(p<0,01)$, In addition, the Hypothesis 2 which posits a positive relationship between competitive intensity and utilisation of advisory services $(\mathrm{p}<0,01)$ is also supported, Support is also provided for Hypothesis $3(\mathrm{p}<0,01)$ which states that the complexity of marketing decisions is significantly positively associated with the use of the advisory services.

Table 3: Results of regression analyses for direct effect

\begin{tabular}{l|l|l}
\hline \multirow{2}{*}{ Variables } & \multicolumn{1}{|c|}{ Advisory Services } & \multicolumn{1}{c}{ Performance } \\
\cline { 2 - 3 } & \multicolumn{1}{|c}{ Model 1 } & \multicolumn{1}{c}{ Model 2 } \\
\cline { 2 - 3 } $\begin{array}{l}\text { Owner/ managers' } \\
\text { knowledge }\end{array}$ & $0,169(0,026)^{* * *}$ & - \\
\hline Competitive intensity & $0,264(0,051)^{* * *}$ & - \\
\hline $\begin{array}{l}\text { Complexity of } \\
\text { marketing decisions }\end{array}$ & $0,417(0,056)^{* * *}$ & - \\
\hline Advisory Services & - & $0,671(0,069)^{* * *}$ \\
\hline Constant & $-2,253(1,385)$ & $60,849(1,452)$ \\
\hline $\mathrm{R}^{2}$ & 0,347 &, 151 \\
\hline Adjusted R ${ }^{2}$ & 0,343 &, 149 \\
\hline F-value & 84,398 & 94,213 \\
\hline DF-Model & 3 & 1 \\
\hline $\begin{array}{l}\text { Note: } \mathrm{n}=658, \text { Unstandardized coefficients reported, Numbers in parentheses } \\
\text { are Standard Errors (S,E), } \\
* * * \text { Significant at the 0,01 level }\end{array}$
\end{tabular}

Additionally, a linear regression analysis was conducted to examine the association between the utilisation of advisory services as the independent variable and performance as the dependent variable in Model 2 of Table 3, The Hypothesis 4 is also supported $(\mathrm{p}<0,01)$ which posits a firm performance improves directly to the extent to which the professional accountants' advisory services are used.

\section{Testing for mediation effects}

To test for the mediating effect of the utilisation of advisory services on the relationship between the three independent variables (owner/managers' knowledge, competitive intensity and complexity of marketing decisions) and firm performance, we performed the analyses under the three conditions suggested by Baron and Kenny (1986) as follows: Firstly, the independent variables (owner/managers' knowledge, competitive intensity and complexity of marketing decisions) must significantly affect the mediating variable (utilisation of advisory services) in a regression of the independent variables on the mediating variable, Secondly, the independent variables (owner/ managers' knowledge, competitive intensity and complexity of marketing decisions) should influence the dependent variable (performance) in a regression of the independent variable on the dependent variable, Thirdly, the mediating variable (utilisation of advisory services) must affect the dependent variable (performance) in a regression of the independent variables and the mediating variable on the dependent variable, If the specified three conditions hold in the predicted direction, then the effect of the independent variables (owner/managers' knowledge, competitive intensity and complexity of marketing decisions) on the dependent variable (performance) in the third condition should be less than in the second condition to create a mediation effect, Consequently, Baron and Kenny (1986) and Lahiri and Kedia (2009) suggested that full mediation takes place if the independent variables have no significant effect on the dependant variable when the mediating variable is in the regression equation, Moreover, they also indicated that partial mediation occurs if the effect of the independent variables reduce in strength (i,e, the change in regression coefficients), but remain statistically significant after controlling for the mediating effect,

Table 4: Results of regression analyses for mediation effects

\begin{tabular}{l|l|l|l}
\hline \multirow{2}{*}{ Variables } & \multicolumn{1}{|c|}{$\begin{array}{c}\text { Advisory } \\
\text { services }\end{array}$} & \multicolumn{2}{|c}{ Performance } \\
\cline { 2 - 4 } & Model 1 & \multicolumn{1}{|c}{ Model 2 } & Model 3 \\
\cline { 2 - 4 } & Coefficient(S,E) & Coefficient(S,E) & Coefficient(S,E) \\
\hline $\begin{array}{l}\text { Owner/ } \\
\text { managers' } \\
\text { knowledge }\end{array}$ & $0,169(0,026)^{* * *}$ & $0,320(0,048)^{* * * *}$ & $0,277(0,051)^{* * * *}$ \\
\hline $\begin{array}{l}\text { Competitive } \\
\text { intensity }\end{array}$ & $0,264(0,051)^{* * *}$ & $0,525(0,094)^{* * *}$ & $0,482(0,099)^{* * *}$ \\
\hline $\begin{array}{l}\text { Complexity } \\
\text { of marketing } \\
\text { decisions }\end{array}$ & $0,417(0,056)^{* * *}$ & $0,336(0,104)^{* * * *}$ & $0,245(0,112)^{* *}$ \\
\hline $\begin{array}{l}\text { Advisory } \\
\text { Services }\end{array}$ & - & & \\
\hline Constant & $-2,253(1,385)$ & $41,449(2,614)$ & $41,387(2,671)$ \\
\hline $\mathrm{R}^{2}$ & 0,347 & 0,252 & 0,276 \\
\hline Adjusted $\mathrm{R}^{2}$ & 0,343 & 0,247 & 0,269 \\
\hline F-value & 84,398 & 54,384 & 42,638 \\
\hline DF-Model & 3 & 3 & 4 \\
\hline
\end{tabular}

Note: $n=658$, Unstandardized coefficients reported, Numbers in parentheses are Standard Errors $(\mathrm{S}, \mathrm{E})$,

*** Significant at the 0,01 level and ** significant at the 0,05 level

We perused the conditions suggested by Baron and Kenny (1986) and conducted multiple regression analyses shown in Table 4, Therefore, the results for Model 1 in Table 4 indicate a significant positive association between independent variables (owner/managers' knowledge, 
competitive intensity and complexity of marketing decisions) and mediating variable (the utilisation of advisory services) ( $p<0,01$, respectively), thereby confirming the first condition. Second condition is also satisfied as owner/managers' knowledge, competitive intensity and complexity of marketing decisions are significantly associated with firm performance (Model 2 of Table 4) ( $\mathrm{p}<0,01$, respectively), Model 3 shows a significant association $(\mathrm{p}<0,01)$ between utilisation of advisory services (mediator variable) and firm performance (dependent variable), confirming the third condition.

However, the effects of the independent variables when combined with the effect of the mediating variable (utilisation of advisory services) in predicting firm performance (Model 3) shows there is a mediation effect when compared to the results presented for Model 2. Accordingly, the positive effects of owner/managers' knowledge, competitive intensity and complexity of marketing decisions reduce in strength (e.g., the change in regression coefficients from 0,320 to $0,277,0,525$ to 0,482 and 0,336 to 0,245 , respectively) and remain statistically significant, Overall, the above results indicate that utilisation of advisory services partially mediate the relationship between owner/managers' knowledge and performance followed by competitive intensity and performance or complexity of marketing decisions and performance. Hence, our Hypothesis 5, 6 and 7 are partially supported.

\section{Discussion}

We have examined from an emerging economy's context, the factors that influence a firm's decision to obtain professional accountants' advisory services and its impact on SME performance. Using the resource-based view, we investigated whether external resources that are considered valuable by SMEs and utilised by them in fulfilling the internal resource gaps influence SME performance. Our empirical analysis shows that firms with owner/managers having high levels of knowledge in accounting will use professional accountants' advisory services more than those firms with owner/managers having low levels of knowledge. In this respect, our finding is similar to Audet and St-Jean (2007) who evidenced that when the SME owner/managers know more about the external service providers, they will utilise their services more. Interestingly, we found that the utlisation of advisory services of a professional accountant is positively associated with competitive intensity. However, our findings contradict a prior study conducted in Norway (Gooderham et al., 2004), which indicated that business advice of professional accountant was not associated with the degree of competition. We believe the reasons could be threefold: Firstly, the previous study was undertaken in a developed country where advisory support to small firms are available from many sources (Mole et al., 2009), and in the context of a developing economy, Iran, the applicability of the RBV theorisation is more apt. Secondly, the sample in this study comprised small and medium sized- enterprises whereas prior research (Gooderham et al., 2004) focused on micro and small enterprises (20 employees), hence suggesting an impact of size on the need for outsourcing of services. Finally, we examined five types of advisory services provided by professional accountant, whereas prior research tested only professional accountants' business advice, clearly this indicates the importance of a variety of services for an emerging economy. Furthermore, this study also found complexity of the marketing decisions is statistically positively associated with professional accountants' advisory services. This finding indicates that SME owner/managers are more willing to use professional accountant when they face complexity in marketplace decisions, hence, providing empirical validation of another study that found a positive relationship between complexity of marketing decisions and business advice (Dyer \& Ross, 2008).

More importantly, the relationship between the utilisation of advisory services and SME performance was investigated, and it is found that a firm's performance improves directly to the extent to which the firm engages a professional accountant as advisor. This is consistent with other advisory services research findings (Bennett \& Robson, 1999; Berry et al., 2006), but this result is contradictory to Robson and Bennet's (2000) research in the UK that did not evidence an association between the professional accountants' business advice and SME performance. Therefore, we can speculate that this may be caused by the context of the developed economy where the SME entrepreneurs could be sufficiently literate on financial and management issues. For example, in an emerging economy, most SMEs face difficulty in attracting and retaining skilled employees or qualified accountants (Devi \& Samujh, 2010; Jayabalan et al., 2009; UNIDO, 2003).

Finally, we examined the mediating role of professional accountants' advisory services on the relationship between owner-managers' knowledge, competitive intensity and complexity of marketing decisions and firm performance. Hence, our findings suggest that utilisation of advisory services partially mediated the association between these three independent variables and firm performance, which is consistent with Dyer and Ross (2008) who found that business advice had a mediation effect on the relationship between the complexity of marketing decisions and performance, but so far no empirical study has examined the mediation effects of accountants' advisory services on the relationship between owner-managers' knowledge and performance or competitive intensity and firm performance, hence the contribution of this study.

\section{Research and practical implications}

Several research and practical implications are noteworthy, Firstly, this study examines the impact of the utilisation of professional accountants' services on SME performance and confirms previous research (Berry et al., 2006), and extends the study by including owner/managers' knowledge, competitive intensity and complexity as critical factors effecting a firm's decision to utilise professional accountants' services, thereby, contributing to the extant literature on emerging economies. Secondly, this study examines the impact of professional accountants' services on SME performance using a Resource Based View, hence, providing some empirical evidence on the applicability of such theory in an emerging economy context. Thirdly, this study also evidences the mediating role of the utilisation of 
the professional accountants' advisory services which has not been highlighted in prior studies. Fourthly, this study is the first to examine the professional accountant's services in the Iranian context, that show cases an emerging economy and it also explicitly demonstrates the services currently provided by accountants to the SME sector. Therefore, identifying the broader range of services currently provided by professional accountants to SMEs and the benefit attached to these services brings into focus the broader range of choices available to SME owner/managers. Fifthly, given the prominent role SMEs play in the Iranian economy with influence over the economic policymaking of the country (Feizpour \& Jamali, 2009; Zohari, 2008), it is clear that research on SMEs has not featured significantly in extant academic research because of the characteristics of SMEs and the difficulties in generalizing the findings (Feizpour \& Jamali, 2009; Zohari, 2008). Accordingly, there is a lack of empirical research regarding the use of the professional accountants' services in Iranian SME environment, so this research aims to overcome and contribute to this field of study. Sixthly, majority of SMEs in developing countries are faced with internal resource gaps; they generally seek support and advisory services to fill up these gaps. Clearly, professional accountants are in a unique position to fullfill the needs of SMEs, but it is important that the advisory and support services are provided by professional accountants to SMEs are fit for purposes (e.g., relevant and high quality). Finally, if professional accountants are to expand their services to SMEs, we suggest that they should enhance their multidisciplinary and expertise base beyond traditional work and move to be knowledge professionals. Whether or not professional accountants can be able to achieve this shift is arguable but this is where efforts of the International Federation of Accountants (Blackburn \& Jarvis, 2010) are evidently critical. This implies the Iranian accounting profession should explore avenues to improve the services offered by professional accountants. This may similarly apply to other emerging economies' professional accounting associations.

\section{Limitations and suggestions future research}

Our results need to be interpreted in the Iranian context. In that respect, it would be interesting for future research to compare our findings with other developed or developing countries. In addition, this study focused on quantitative method using questionnaire survey, thus future research should employ qualitative approach in order to investigate the effect of advisory services on SME performance. Besides, we utilised subjective measures of SME performance, but it may be useful to examine objective measures of performance (i.e., percentage of profits) within a specific industry for future study. Finally, this research was conducted on manufacturing SMEs, so generalization to other sectors may be made with caution.

\section{Conclusion}

This study examined the factors impacting a firm's decision to obtain professional accountants' advisory services and its effect on SME performance by using a sample of Iranian SMEs in the manufacturing sector. Our findings indicate that owner/managers' knowledge, competitive intensity and complexity of marketing decisions are critical factors affect a firm's decision to engage professional accountants' services in Iranian SME context. Interestingly, our findings suggest the use of the professional accountants' advisory services is significantly and positively associated with SME performance. This study also finds that use of advisory services has a partial mediating role on the relationship between owner/managers' knowledge, competitive intensity and complexity of marketing decisions and SME performance.

\section{References}

ArabSalehi, M. \& Velashani, M. A. B. 2009. 'Financial reporting gap in developing countries: The case study of Iran', Middle Eastern Finance and Economics, 3: 77-78.

Ale Ebrahim, N., Ahmed, S. \& Taha, Z. 2009. 'Virtual R\&D teams in small and medium enterprises: A literature review', Scientific Research and Essays, 4(13):1575-1590.

Armstrong, J. \& Overton, T. 1997. 'Estimating nonresponse bias in mail surveys', Journal of Marketing Research, 3: 396-402.

Audet, J. \& St-Jean, E. 2007. 'Factors affecting the use of public support services by SME owners: Evidence from a periphery region of Canada', Journal of Developmental Entrepreneurship 12(2): 165-180.

Baron, R. M. \& Kenny, D.A. 1986. 'The moderator mediator variable distinction in social psychological research: Conceptual, strategic, and statistical considerations', Journal of Personality and Social Psychology, 51(6): 1173-1182.

Bayati, A. \& Taghavi, A. 2007. 'The impacts of acquiring ISO 9000 certification on the performance of SMEs in Tehran', The TQM Magazine, 19(2): 140-149.

Bennett, R. 2008. 'SME policy support in Britain since the 1990s: what have we learnt? ', Environment and Planning C: Government and Policy, 26: 375 - 397.

Bennett, R. \& Robson, P. 1999. 'The use of external business advice by SMEs in Britain', Entrepreneurship and Regional Development, 11(2): 155-180.

Bennett, R. \& Robson, P. 2003. 'Changing use of external business advice and government support by SMEs in the 1990s', Regional Studies, 37(8): 795-811.

Bennett, R. \& Robson, P. 2004. 'Support services for SMEs: Does the 'franchisee' make a difference to the Business Link offer?', Environment and Planning C: Government and Policy, 22: 859 - 880,

Berry, A. J., Sweeting, R. \& Goto, J. 2006. 'The effect of business advisers on the performance of SMEs', Journal of Small Business and Enterprise Development, 13(1): 33-47.

Blackburn, R. \& Jarvis, R. 2010. 'The role of small and medium practices in providing business support to small- 
and medium-sized enterprises'. Information Paper, International Federation of Accountants, April.

Burns, A. C. \& Bush, R. F. 2000. Marketing research. $3^{\text {rd }}$ Edition. Upper-Saddle River, New Jersey: Prentice Hall, Inc.

Carey, P., Simnett, R. \& Tanewski, G. 2005. Providing business advice for small to medium enterprises. Melbourne: CPA Australia.

Collis, J. \& Jarvis, R. 2002. 'Financial information and the management of small private companies,' Journal of Small Business and Enterprise Development, 9(2): 100-110.

Curran, J. \& Blackburn, R. A. 2000 'Policy review section: Panacea or white elephant? A critical examination of the proposed new small business service and response to the DTI consultancy paper', Regional Studies, 34(2): 181-206.

Devi, S. S. \& Samujh, R. H. 2010. Accountants as providers of support and advice to SMEs in Malaysia. Research report No. 118. London: ACCA.

Doran, M. 2006. 'Bean counter or business adviser? An exploratory study of changing times for the accounting practitioner in Ireland', The Irish Accounting Review, 13(1): 23-46.

Doving, E. \& Gooderham, P.N. 2008. 'Dynamic capabilities as antecedents of the scope of related diversification: The case of small firm accountancy practices', Strategic Management Journal, 29(8): 841-857.

Dyer, L.M. \& Ross, C.A. 2008. 'Seeking advice in a dynamic and complex business environment: Impact on the success of small firms', Journal of Developmental Entrepreneurship, 13(2): 133-149.

Espino-Rodríguez, T.F. \& Padrón-Robaina, V. 2004. 'Outsourcing and its impact on operational objectives and performance: A study of hotels in the Canary Islands', Hospitality Management, 23: 287-30.

Everaert, P., Sarens, G. \& Rommel, J. 2006. Outsourcing of accounting tasks in SMEs: An extended TCE Model, Working Paper No, 2004/403. Gent: Univeersiteit Gento.

Everaert, P., Sarens, G. \& Rommel, J. 2007. 'Sourcing strategy of Belgian SMEs: Empirical evidence for the accounting services', Production Planning \& Control, 18(8): 716-725.

Everaert, P., Sarens, G. \& Rommel, J. 2010. 'Using transaction cost economics to explain outsourcing of accounting', Small Bus Econ, 35(1): 93-112.

Fathian, M. \& Amiri, B. 2006. 'The evaluation of e-business indicators in the Iranian SMEs', New Economy and Commerce, 4: 5-23

Feizpour, M.A. \& Jamali, R. 2009. 'SMEs employees gender composition and firm growth: Evidence from manufacturing industry in cooperative sector during the Second Development Plan in Iran from 1995 to 1999', International Review of Business Research Papers, 5(3): 311-332.

Gainey, T.W. \& Klaas, B.S. 2003. 'The outsourcing of training and development: Factors impacting client satisfaction', Journal of Management Accounting Research, 29(2): 207-229.

García-Teruel, P.J. \& Martínez-Solano, P. 2010. 'Determinants of trade credit: A comparative study of European SMEs', International Small Business Journal, 28(3): 215-233.

Gilley, K.M., Greer, C.R. \& Rasheed, A.A. 2004. 'Human resource outsourcing and organizational performance in manufacturing firms', Journal of Business Research, 57: 232-240,

Gooderham, P.N., Tobiassen, A., Doving, E. \& Nordhaug, O. 2004. 'Accountants as sources of business advice for small firms', International Small Business Journal, 22(1): 522.

Gottschalk, P. \& Solli-Sæther, H. 2005. 'Critical success factors from IT outsourcing theories: An empirical study', Industrial Management \& Data Systems, 105(6): 685-702.

Greenwood, R., Suddaby, R. \& Hinings, C.R. 2002. 'Theorizing change: The role of professional associations in the transformation of institutionalized fields', Academy of Management Journal, 45(1): 58-80.

Gunasekaran, A., Marri, H.B. \& Grieve, R.J. 1999. 'Activity based costing in small and medium enterprises', Computers \& Industrial Engineering, 37: 407-411.

Hadjimanolis, A. 2000. 'A resourced-based view of innovativeness in small firms', Technology Analysis and Strategic Management, 12(2): 263- 292.

Hafeez, K., Malak, N. \& Zhang, Y.B. 2007. 'Outsourcing non-core assets and competences of a firm using analytic hierarchy process', Computers \& Operations Research, 34: $3592-3608$.

ILO. 2003. 'An employment strategy for the Islamic Republic of Iran: A report prepared for the Government of the Islamic Republic of Iran in collaboration with the Ministry of Labour and Social Affairs under UNDP SPPD funding.' [online] URL:

http://www,ilo,org/public/english/region/asro/newdelhi/dow nload/publ/iran/strategy_rep,pdf.

Irwin, J., Hoffman, J. \& Lamont, B. 1998. 'The effect of the acquisition of technological innovations on organizational performance: A resource-based view', Journal of Engineering \& Technology Management, 15(1): 23-54.

Ismail, N.A. \& King, M. 2005. 'Firm performance and AIS alignment in Malaysian SMEs', International Journal of Accounting Information Systems, 6: 241- 259. 
Ismail, N.A. \& King, M. 2006. 'The alignment of accounting and information systems in SMEs in Malaysia', Journal of Global Information Technology Management, 9(3): 24-42.

Ismail, N.A. \& King, M. 2007. 'Factors influencing the alignment of accounting information systems in small and medium sized Malaysian manufacturing firms', Journal of Information Systems and Small Business, 1(1-2): 1-20.

Ismail, N.A. \& Zin, R.M. 2009. 'Usage of accounting information among Malaysian Bumiputra small and medium non-manufacturing firms', Journal of Enterprise Resource Planning Studies, 1(2): 11-17.

Jayabalan, J., Raman, M., Dorasamy, M. \& Ching, N.K.C. 2009. 'Outsourcing of accounting functions amongst SME companies in Malaysia: An exploratory study,' Accountancy Business and the Public Interest, 8(2): 96-114.

Johnson, S., Webber, D.J. \& Thomas, W. 2007. 'Which SMEs use external business advice? A multivariate subregional study', Environment and Planning A, 39: 1981 $-1997$.

Kirby, D.A., Najak, B. \& Greene, F. 1998. Accounting for growth: Ways accountants can add value to small businesses. London: The Research Board, ICAEW.

Lahiri, S. \& Kedia, B.L. 2009. 'The effects of internal resources and partnership quality on firm performance: An examination of Indian BPO providers', Journal of International Management, 15: 209-224.

Lamminmaki, D. 2008. 'Accounting and the management of outsourcing: An empirical study in the hotel industry', Management Accounting Research, 19: 163-181.

Leung, P., Raar, J. \& Tangey, G. 2008. Accounting services and SMEs: An Australian study. ACCA Research Report No. 99. London: CAET,

Lewis, K., Massey, C., Ashby, M., Coetzer, A. \& Harris, C. 2005. 'Who? When? Why? - New Zealand SME ownermanagers assess their Business Assistance Interactions'. Paper presented at the $8^{\text {th }}$ Annual SEAANZ Conference 2005 UNE, Armidale, 25-28 September.

Lowe, P. \& Talbot, H. 2000. Providing advice and information in support of rural micro businesses. University of Newcastle, Centre for Rural Economy.

Mahmoodzadeh, E., Jalalinia, S. \& Yazdi, F.N. 2009. 'A business process outsourcing framework based on business process management and knowledge management', Business Process Management Journal, 15(6): 845-864.

Marriott, N. \& Marriott, P. 2000. 'Professional accountants and the development of a management accounting service for the small firm: Barriers and possibilities', Management Accounting Research, 11: 475-492.
Marriott, N., Marriott, P., Collis, J. \& Son, D.D. 2008. 'The accountant and the provision of financial advice to UK smaller companies'. Paper presented at the British Accounting Association Annual Conference 1st-3rd April 2008, Blackpool.

Marshall, D., McIvor, R. \& Lamming, R. 2007. 'Influences and outcomes of outsourcing: Insights from the telecommunications industry', Journal of Purchasing \& Supply Management, 13: 245-260.

Martin, C. 2005. Accountancy practices and the provision of ownership succession advice. ACCA Research Report No. 85. London: CAET.

Mashayekhi, B. \& Mashayekh, S. 2008. 'Development of accounting in Iran', The International Journal of Accounting, 43: 66-86.

McIvor, R. 2009. 'How the transaction cost and resourcebased theories of the firm inform outsourcing evaluation', Journal of Operations Management, 27: 45-63.

Mirshekary, S. \& Saudagaran, S.M. 2005. 'Perceptions and characteristics of financial statement users in developing countries: Evidence from Iran', Journal of International Accounting, Auditing and Taxation, 14: 33-54.

Mole, K. 2002. 'Business advisers' impact on SMEs: An agency theory approach', International Small Business Journal, 20(2): 139-162.

Mole, K., Hart, M., Roper, S. \& Saal, D. 2009. 'Assessing the effectiveness of business support services in England: Evidence from a theory-based evaluation', International Small Business Journal, 27(5):557-582.

Naderian, H. 2010. 'Several obvious and significant differences in professional services in Iran', Journal of Iranian Certified Public Accountants, 8: 44-45.

Nejad, O.D. 2010. 'A note on the post-revolution Iranian economy and the banking sector', Middle Eastern Finance and Economics, 6: 91-98.

OECD. 2009. The impact of the global crisis on SME and entrepreneurship financing and policy responses. Centre for Entreprenuership, SMEs and Local Development, Organisation for Economic Co-operation and Development.

Penrose, E.T. 1959. The theory of the growth of the firm. Oxford: Basil Blackwell.

Pineda, R.C., Lerner, L.D., Miller, M.C. \& Phillips, S.J. 1998. 'An investigation of the factors affecting the information-search activities of small business managers', Journal of Small Business Management, 36(1): 60-71.

Rivard, S., Raymond, L. \& Verreaul, D. 2006. 'Resourcebased view and competitive strategy: An integrated model of the contribution of information technology to firm performance', Journal of Strategic Information Systems, 15: 29-50. 
Robson, P.J.A. \& Bennett, R.J. 2000. 'SME growth: The relationship with business advice and external collaboration', Small Business Economics, 15(3): 193-208.

Roy, V. \& Aubert, B.A. 2002. 'A resource-based analysis of IT sourcing', The Databases for Advances in Information Systems, 33(2): 29-40/.

Salehi, M. \& Azary, Z. 2008. 'Fraud detection and audit expectation gap: Empirical evidence from Iranian bankers', International Journal of Business and Management, 3(10): 65-77.

Samujh, R.H. \& Devi, S.S. 2008. 'Professional accountants enabling SMEs reach their potential'. Paper presented at the International Colloquium on Asian Business, Bangkok, Thailand, 30 June-3 July, 1-25.

Sarapaivanich, N. \& Kotey, B. 2006. 'The effect of financial information quality on ability to access external funds and performance of SMEs in Thailand', Journal of Enterprising Culture, 14(3): 219-239.

Scott, J.M. \& Irwin, D. 2009. 'Discouraged advisees? The influence of gender, ethnicity, and education in the use of advice and finance by UK SMEs', Environment and Planning C: Government and Policy, 27: 230 -245.

Sian, S. \& Roberts, C. 2009. 'UK small owner-managed businesses: Accounting and financial reporting needs', Journal of Small Business and Enterprise Development, 16(2): 289-305.

Ulubasoglu, M.A., Akdis, M. \& Kök, S.B. 2010. 'Internationalization and alliance formation: Evidence from Turkish SMEs', International Small Business Journal, 27(3): 337-361.

UNIDO. 2003. 'To enhance the contribution of an efficient and competitive small and medium-sized enterprise sector to industrial and economic development in the Islamic republic of Iran'. [online]

URL:http://www,unido,org/fileadmin/import/18229_AbsFin al,pdf

Watson, J. 2003. 'The potential impact of accessing advice on SME failure rates'. Paper presented at the Small Enterprise Association of Australia and New Zealand $16^{\text {th }}$ Annual Conference, Ballarat, 28 September.

Worrall, L. 2007. 'Transforming regional economic performance through business transformation', International Journal of Management Practice, 2(4): 324 - 344.

Zohari, T. 2008. 'Iranian government globalization policy impacts on SMEs and the corresponding effect on IranianSwedish trade'. [online] URL:

http://digitpro,co,uk/paper/iran_sweden,pdf 